\title{
Pengaruh Motivasi, Komitmen Organisasi dan Pengawasan terhadap Kinerja Karyawan PT. Kalimantan Prima Persada (KPP)
}

\author{
Erma Hereyanti ${ }^{1}$, Muhammad Jahri ${ }^{2}$, TA Hariyono ${ }^{3}$ \\ Universitas Merdeka Malang ${ }^{1}$, STIMI Banjarmasin ${ }^{2,3}$ \\ Alamat Instans lamat Jl. Terus Dieng No. 62, Malang, Jawa Timur1 \\ Alamat Jl. Kuripan No. 26 Banjarmasin, Kalimantan Selatan ${ }^{2}$ \\ ermahereyanti7@gmail.com ${ }^{1}$ \\ muhammadjahri.stimibjm@gmail.com ${ }^{2}$ \\ hariyono.stimibjm@gmail.com ${ }^{3}$
}

\begin{abstract}
The study was conducted to explore the relationship of Motivation, Organizational Commitment and Supervision on Employee Peformance on PT. Kalimantan Prima Persada (KPP). The populatian of this study is 236 employees of PT. Kalimantan Prima Persada (KPP). In order to determine the sample, this study used Slovin Formula. The questionnaires were distributed to 70 sample respondents. The data were analyzed by using SPSS Software Version 19.0 and Linear Regression. The result showed that Motivation, Organizational Commitment and Supervision has a significant on Employee Peformance
\end{abstract}

Keyword- Motivation, Organizational Commitment, Supervision, Employee Peformance

Abstrak - Penelitian ini dilakukan untuk mengeksplorasi hubungan Motivasi, Komitmen Organisasi, dan Pengawasan terhadap Kinerja Karyawan di PT. Kalimantan Prima Persada (KPP). Populasi penelitian ini adalah 236 karyawan PT. Kalimantan Prima Persada (KPP). Untuk menentukan sampel, penelitian ini menggunakan Slovin Formula. Kuesioner dibagikan kepada 70 responden sampel. Data dianalisis dengan menggunakan SPSS Software Versi 19.0 dan Regresi Linier. Hasil penelitian menunjukkan bahwa Motivasi, Komitmen Organisasi, dan Pengawasan berpengaruh signifikan terhadap Kinerja Pegawai

Kata Kunci- Motivasi, Komitmen Organisasi, Pengawasan, Kinerja Karyawan

\section{PENDAHULUAN}

Di dalam sebuah organisasi dituntut untuk mengoptimalkan Sumber Daya Manusia (SDM) dalam sebuah pengelolaan yang baik. Pengelolaan Sumber Daya Manusia (SDM) tentunya tidak terlepas dari faktor pimpinan dan karyawan untuk dapat memberikan prestasi yang terbaik dalam hal pencapaian tujuan organisasi. Karyawan merupakan asset utama suatu organisasi dan mempunyai peran strategis di dalam organisasi tersebut. Demi tercapainya tujuan organisasi maka kinerja karyawan perlu dioptimalkan lagi, semakin banyak karyawan yang memiliki kinerja yang tinggi, maka akan dapat memberikan kontribusi ekonomi perusahaan dalam persaingan global. Kinerja menjadi faktor penentu bagi setiap individu dan organisasi. Amstrong dan Baron (dalam Fahmi 2010) mengatakan kinerja merupakan hasil pekerjaan yang mampu mempunyai hubungan kuat dengan tujuan strategis organisasi kepuasan konsumen dan memberikan kontribusi ekonomi, sehingga kinerja yang tinggi sangat diharapkan oleh organisasi. Untuk mencapai tujuan organisasi ada beberapa faktor yang dapat mempengaruhi kinerja karyawan yaitu motivasi dan komitmen organisasi.

Motivasi sangat diperlukan dalam sebuah organisasi/ perusahaan sebagai tolak ukur penilaian kinerja karyawan. Karyawan yang mempunyai motivasi yang tinggi dapat memperlihatkan kinerja yang optimal bagi organisasi/ perusahaan tersebut.

Menurut Ernest J. McCornick mengemukakan bahwa motivasi didefinisikan sebagai kondisi yang berpengaruh membangkitkan, mengarahkan dan memelihara perilaku-perilaku yang berhubungan dengan lingkungan kerja. Sehingga, seorang pemimpin harus memberikan motivasi kepada karyawan supaya lebih memiliki semangat dalam melaksanakan pekerjaan, dengan termotivasi karyawan akan lebih meningkatkan kinerjanya lagi. Selain Motivasi ada Komitmen Organisasi yang berperan penting juga didalam suatu organisasi/ perusahaaan. Menurut Moorhead dan Griffin (2013) Komitmen Organisasi adalah sikap yang mencerminkan sejauh mana seseorang individu mengenal dan terikat pada organisasinya. Menurut Mar'at (2000:87), komitmen 
seorang pegawai dipengaruhi oleh beberapa faktor seperti motivasi, kompensasi, pelatihan, fungsi pemimpin, iklim kerja sama, semangat kerja, dan konflik yang terjadi dalam suatu kantor. Karyawan yang memiliki komitmen organisasional tinggi memiliki perbedaan sikap dibandingkan yang berkomitmen rendah. Karyawan yang berkomitmen tinggi, mereka akan bekerja dengan sungguh-sungguh, bekerja sebaik mungkin agar kinerja mereka meningkat, dan mau bertahan diorganisasi.

PT. Kalimantan Prima Persada (KPP) merupakan sebuah perusahaan jasa penambangan terpadu didirikan untuk menetapkan sebuah konsep baru pengembangan untuk memperluas pasar dan memberikan layanan penambangan batubara dari kontrak perdagangan PT. Kalimantan Prima Persada (KPP) memiliki visi untuk diakui sebagai perusahaan jasa pertambangan terintegrasi terbesar di Indonesia, namun untuk mencapai tujuan tersebut tentunya harus didukung oleh para karyawannya untuk berperilaku sesuai komitmen organisasi yang sama-sama telah disepakati bersama, salah satu komitmen organisasi terkait dengan tingkat kehadiran pada PT. Kalimantan Prima Persada (KPP) yang terlihat pada tabel 1.1 berikut:

Tabel 1

Laporan Presensi Karyawan PT. Kalimantan Prima Persada (KPP)

Mei s.d Agustus 2018

\begin{tabular}{lcccccccccc}
\hline \multicolumn{1}{c}{ Bulan } & $\begin{array}{c}\text { Jumlah } \\
\text { Karyawan }\end{array}$ & \multicolumn{2}{c}{ Sakit } & \multicolumn{2}{c}{ Ijin } & \multicolumn{2}{c}{ Tanpa Ket. } & \multicolumn{2}{c}{ Total } \\
\hline Mei 2018 & 225 & 27 & 0,48 & 22 & 0,39 & - & 0,00 & 49 & 0,87 \\
\hline Juni 2018 & 225 & 36 & 0,64 & 28 & 0,50 & 1 & 0,02 & 65 & 1,16 \\
\hline Juli 2018 & 225 & 46 & 0,82 & 31 & 0,55 & - & 0,00 & 77 & 1,37 \\
\hline Agustus 2018 & 225 & 52 & 0,92 & 64 & 1,14 & - & 0,00 & 116 & 2,06 \\
\hline
\end{tabular}

Sumber : SDM PT. Kalimantan Prima Persada (KPP), data diolah

Terlihat dari tabel 1 tersebut diatas tingkat ketidakhadiran karyawan pada 4 (empat) bulan terakhir sangat tinggi oleh karena itu, dapat dikatakan motivasi dan komitmen organisasi pada karyawan mengalami penurunan dalam kinerjanya, efektifitas suatu perusahaan seharusnya dapat dilihat dari interaksi kerja pada tingkat individual, kelompok bahkan system dalam perusahaan tersebut yang terlihat dari karyawan yang memiliki tingkat kehadiran rendah, namun begitu kebutuhan dan keinginan dari karyawan sebagai Sumber Daya Manusia (SDM) juga perlu diperhatikan dan didukung oleh perusahaan agar karyawan dapat termotivasi untuk berkinerja dengan baik . Pekerjaan merupakan lebih dari sekedar aktifitas mengatur kertas, menulis, kode program, menunggu pelanggan, atau mengendarai sebuah alat transportasi saja, setiap pekerjaan menuntut interaksi dengan rekan kerja dan pimpinan, mengikuti peraturan dan kebijakan perusahaan, memenuhi standar kinerja, menerima kondisi kerja yang kurang ideal, sehingga dibutuhkan kontribusi karyawan yang memiliki komitmen dalam organisasi.

Pengawasan juga sangat diperlukan dalam meningkatkan Kinerja Karyawan, perusahaan selalu menemukan kesalahan dalam bekerja dan penyimpangan-penyimpangan dalam melakukan pekerjaan di dalam perusahaan, sehingga hal tersebut dapat merugikan perusahaan, oleh karena itu pengawasan sangatlah diperlukan. Menurut Hasibuan (2011:154) pengawasan adalah kegiatan pimpinan yang mengusahakan agar pekerjeaan - pekerjaan dapat terlaksana sesuai dengan rencana yang ditetapkan dana tau hasil yang dikehendaki. Pentingnya pengawasan dalam sebuah perusahaan merupakan suatu hal yang serius, oleh karena itu pengawasan harus dilakukan secara optimal dan berkala sehingga akan memberikan efek nantinya terhadap Kinerja Karyawan.

PT. Kalimantan Prima Persada (KPP) sebagai fokus penelitian karena memiliki nilai strategis sebagai perusahaan di bidang pertambangan yang memiliki kompleksitas cukup tinggi di dalam dinamika perusahaan tambang dan energy terutama dalam hal Kinerja Karyawannya, tentu saja dapat terlihat dari Motivasi, Komitmen Organisasi, dan Pengawasan yang dituntut harus dapat mendorong dalam memberikan produktivitas usaha yang tinggi dalam kegiatan sehari-harinya. Situasi dan kondisi inilah yang menuntut perusahaan untuk lebih mengedepankan peran karyawan PT. Kalimantan Prima Persada (KPP), sehingga penting dilakukan pengujian Motivasi, Komitmen Organisasi dan Pengawasan terhadap Kinerja Karyawan PT. Kalimantan Prima Persada (KPP).

\section{Kinerja Karyawan}

\section{KAJIAN PUSTAKA}

Kinerja berasal dari kata Job Performance atau Actual Performance yang memiliki arti prestasi kerja yang dicapai oleh seseorang. Kinerja adalah hasil kerja yang dicapai seseorang dalam melakukan tugas-tugas yang dibebankan kepadanya yang didasarkan atas kecakapan, pengalaman, dan ketangguhan serta waktu.
Komitmen
berkelanjutan
(continuance commitment) yang tinggi akan bertahan di organisasi, bukan karena alasan emosional, tetapi karena adanya kesadaran dalam individu tersebut akan kerugiaan 
yang akan dialami jika meninggalkan organisasi. Kinerja karyawan adalah tingkat hasil kerja karyawan dalam mencapai persyaratan-persyaratan pekerjaan yang diberikan. Kinerja adalah hasil kerja karyawan baik dari segi kualitas maupun kuantitas berdasarkan standar kerja yang telah ditetapkan (Simamora, 2007). Robbins, S.P., (2007), kinerja adalah suatu ukuran yang mencakup keefektifan dalam pencapaian tujuan atau efisiensi yang merupakan rasio dari keluaran efektif, terhadap masukan yang diperlukan untuk mencapai tujuan itu. Jadi jika seorang telah diterima, ditempatkan pada suatu organisasi / unit kerja tertentu mereka harus dikelola agar menunjukkan kinerja yang baik. Siapa yang bertanggung jawab terhadap kinerja. mereka adalah setiap pemimpin pada semua level. Sedangkan Anwar Prabu Mangkunegara (2011:67) mengemukakan bahwa kinerja adalah hasil kerja secara kualitas dan kuantitas yang dicapai oleh seorang pegawai dalam melaksnakan tugasnya sesuai dengan tanggung jawab yang diberikan kepadanya

Berdasarkan pengertian dari kinerja pegawai menurut para ahli, maka dapat dikatakan bahwa kinerja pegawai adalah suatu hasil yang dicapai pegawai dalam pelaksanaan tugasnya baik secara kualitas dan kuantitas dengan standart uncriteria yang telah ditetapkan secara konkrit dan dapat diukur dalam kurun waktu tertentu.

Motivasi

Motivasi (Hasibuan, 2011) berasal dari kata Latin movere yang berarti dorongan atau menggerakkan. Motivasi (motivation) dalam manajemen hanya ditujukan pada sumber daya manusia umumnya dan bawahan khususnya. Motivasi mempersoalkan bagaimana caranya mengarahkan daya dan potensi bawahan, agar mau bekerja sama secara produktif berhasil mencapai dan mewujudkan tujuan yang telah ditentukan. Motivasi adalah "hal yang menyebabkan, menyalurkan dan mendukung perilaku manusia, supaya mau bekerja giat dan antusias mencapai hasil yang optimal". Mangkunegara (2012) juga mengemukakan motivasi adalah "kondisi atau energi yang menggerakkan diri karyawan yang terarah atau tertuju untuk mencapai tujuan organisasi perusahaan". Sutrisno (2013) mengemukakan motivasi adalah "faktor yang mendorong seseorang untuk melakukan suatu aktivitas tertentu, motivasi sering kali diartikan pula sebagai faktor pendorong perilaku seseorang". Komitmen Organisasi
Komitmen Organisasi merupakan sikap pegawai yang tertarik dengan tujuan, nilai dan sasaran organisasi yang ditunjukkan dengan adanya penerimaan individu atas nilai dan tujuan organisasi serta emmiliki keinginan untuk berhubungan dengan organisasi kesediaan bekerja keras sehingga individu tersebut tetap ingin bertahan di organisasi tersebut demi tercapainya tujuan dan kelangsungan organisasi.

Menurut Allen dan Meyer dalam Darmawan (2013) mendefinisikan komitmen organisasi adalah sebuah konsep yang memiliki tiga dimensi, yaitu komitmen afektif, berkelanjutan dan normative. Kemudian menurut Robbin and Judge (2011) mengatakan bahwa komitmen organisasi didefinisikan sebagai kekuatan yang bersifat relative dari individu dalam mengidentifikasi keterlibatan dirinya kedalam bagian organisasi yang dicirikan oleh penerimaan nilai dan tujuan organisasi, kesediaan berusaha demi organisasi dan keinginan mempertahankan keanggotaan dalam organisasi.

Berdasarkan beberapa pendapat dari para ahli diatas, dapat dikatakan bahwa komitmen organisasi merupakan rasa kepercayaan akan nilai - nilai organisasi, serta kesetiaan terhadap organisasi untuk berkarya dan memilki keinginan yang kuat untuk bertahan di organisasi.

Pengawasan

Kepemimpinan (leadership) yang ditetapkan oleh seorang manajer dalam organisasi dapat menciptakan integrasi yang serasi dan mendorong gairah kinerja karyawan untuk mencapai sasaran yang maksimal. Pada kenyataannya pemimpin dapat mempengaruhi moral dan kepuasan kerja, kualitas kehidupan kerja dan terutama tingkat prestasi suatu organisasi. Untuk mencapai semua itu seorang pemimpin harus mempunyai kemampuan dan keterampilan kepemimpinan dalam melakukan pengarahan kepada bawahannya untuk mencapai tujuan suatu organisasi. Thoha (2003) menjelaskan kepemimpinan terkadang diartikan sebagai pelaksana otoritas dan pembuatan keputusan, tetapi terkadang ada yang mengartikan kepemimpinan sebagai suatu inisatif untuk bertindak yang menghasilkan suatu pola yang konsisten dalam rangka mencari jalan pemecahan dari suatu persoalan bersaman. Selanjutnya Rivai (2003) menjelaskan kepemimpinan secara luas meliputi proses mempengaruhi dalam menentukan tujuan organisasi, memotivasi perilaku pengikut untuk mencapai tujuan, 
mempengaruhi untuk memperbaiki kelompok dan budayanya. Kepemimpinan hanyalah sebuah alat, sarana atau secara suka rela/ suka cita.

\section{Rancangan Penelitian}

\section{METODE PENELITIAN}

Penelitian ini merupakan penelitian deskriptif dan kuantitatif. Penelitian ini membangun gambaran sesungguhnya terhadap suatu fenomena yang terjadi. Dimana penelitian deskriptif ini akan dikumpulkan berbagai informasi dalam rangka pengujian pengaruh terhadap variabel-variabel yang diteliti. Perencanaan penelitian, perumusan masalah dan penyusunan hipotesis digunakan kerangka teoritis mengenai konsep-konsep dan teori-teori tentang Motivasi, Komitmen Organisasi, Pengawasan dan Kinerja Karyawan yang diambil dari beberapa literatur. Untuk dilakukan pengkajian seluruh permasalahan penelitian, data yang diperlukan diperoleh melalui survei lapangan dengan menggunakan kuesioner, setelah itu dilakukan analisis dan uraian terhadap seluruh permasalahan melalui analisis data, perhitungan statistik dan interpretasi data.

Definisi Konseptual Variabel Penelitian

1. Motivasi (X1) adalah merupakan faktor yang mendorong seseorang untuk melakukan suatu aktivitas tertentu, motivasi sering kali diartikan pula sebagai faktor pendorong perilaku seseorang (Sutrisno, 2013)

2. Komitmen Organisasi (X2) merupakan kekuatan yang bersifat relative dari individu dalam mengidentifikasi keterlibatan dirinya kedalam bagian organisasi yang dicirikan oleh penerimaan nilai dan tujuan organisasi, kesediaan berusaha demi organisasi dan keinginan mempertahankan keanggotaan dalam organisasi. (Robbin and Judge, 2011)

3. Pengawasan (X3) adalah suatu cara organisasi mewujudkan kinerja yang efektif dan efesien, serta lebih jauh mendukung terwujudnya visi dan misi organisasi (Fahmi, 2013).

4. Kinerja Karyawan (Y) adalah Kinerja adalah hasil kerja karyawan baik dari segi kualitas maupun kuantitas berdasarkan standar kerja yang telah ditetapkan (Simamora, 2007)

Definisi Operasional Variabel Penelitian

1. Variabel Motivasi (X1) merupakan bagaimana cara mengarahkan daya dan potensi bawahan, agar mau bekerja sama secara produktif berhasil mencapai dan mewujudkan tujuan yang telah ditentukan.
2. Variabel Komitmen Organisasi (X2) adalah sikap pegawai yang tertarik dengan tujuan, nilai dan sasaran organisasi yang ditunjukkan dengan adanya penerimaan individu atas nilai dan tujuan organisasi serta emmiliki keinginan untuk berhubungan dengan organisasi kesediaan bekerja keras sehingga individu tersebut tetap ingin bertahan di organisasi tersebut demi tercapainya tujuan dan kelangsungan organisasi.

3. Pengawasan (X3) merupakan kegiatan yang dilakukan dalam usaha menilai hasil pekerjaan serta mengadakan tindakan bila terjadi penyimpangan-penyimpangan agar tujuan dapat tercapai sesuai dengan rencana yang telah ditetapkan.

4. Variabel Kinerja Pegawai (Y) adalah tingkat hasil kerja pegawai dalam mencapai persyaratan persyaratan pekerjaan yang diberikan.

Populasi dan Sampel Penelitian

1. Populasi

Populasi juga bukan sekedar jumlah yang ada pada obyek/subyek yang dipelajari, tetapi meliputi seluruh karakteristik/sifat yang dimiliki oleh subyek atau obyek itu. Oleh karena itu, unit analisis penelitian sekaligus populasi yang menjadi responden dalam penelitian ini adalah karyawan tetap PT. Kalimantan Prima Persada (KPP) sejumlah 236 orang, seperti tampak pada tabel 1 berikut:

Tabel 1

Jumlah Karyawan Tetap PT. Kalimantan Prima Persada (KPP)

\begin{tabular}{ccc}
\hline No. & Unit Kerja & Jumlah \\
\hline 1. & Head Office Jakarta & 32 \\
2. & Site Office Banjarmasin & 56 \\
3. & Site Office Martapura & 27 \\
4. & Site Office Rantau & 11 \\
5. & Site Office Asam-asam & 88 \\
6. & Site Office Balikpapan & 22 \\
\hline & Total & 236 \\
\hline
\end{tabular}

Sumber : PT. Kalimantan Prima Persada, data diolah lagi oleh penulis

2. Sampel

Mengingat penelitian ini menggunakan unit analisis PT. Kalimantan Prima Persada (KPP), maka besarnya populasi penelitian ialah keseluruhan karyawan analisis PT. Kalimantan Prima Persada (KPP) sebanyak 236 Orang. 
Apabila populasi sudah diketahui, maka dasar penetuan jumlah sampel agar memberikan hasil yang akurat, salah satunya menggunakan formulasi Slovin (Amirin, 2011), sebagai berikut:

$\mathrm{n}=$ Ukuran Sampel

$$
n=\frac{N}{1+N e^{2}}
$$

$\mathrm{N}=$ Ukuran Populasi

e $=$ Prosentase kelonggaran ketidaktelitian yang

masih dapat ditolerir

Dengan menggunakan Formula Slovin, maka

dapat ditentukan besarnya sampel responden

karyawan sebagai berikut :

$$
n=\frac{236}{1+236(0,10)^{2}}=70,23 \rightarrow 70
$$

Berdasarkan hasil perhitungan dengan formula slovin, maka dapat diketahui besarnya sampel responden karyawan yang bekerja pada PT. Kalimantan Prima Persada (KPP) yaitu minimal sebanyak 70,23 orang atau dibulatkan menjadi 70 orang karyawan tetap yang bekerja pada PT. Kalimantan Prima Persada (KPP), untuk mendapatkan sebaran masing-masing sampel responden yang tersebar pada 6 (enam) Bagian Pekerjaan di PT. Kalimantan Prima Persada (KPP) secara proporsional.

Teknik Pengumpulan Data

1. Studi Dokumen

Mengumpulkan data dan informasi dengan mempelajari sumber data tertulis untuk memperoleh data sekunder tentang jumlah karyawan. Data sekunder penelitian ini didapat dari data HRD PT. Kalimantan Prima Persada (KPP).

2. Kuisioner

teknik pengumpulan data yang dilakukan dengan cara memberi seperangkat pertanyaan atau pernyataan tertulis kepada responden untuk dijawab. Kuisioner ini dimaksudkan untuk memperoleh data berupa informasi secara tertulis langsung dari responden (Sugiyono, 2003).

Teknik Analisas Data

1. Analisis Deskriptif

Analisisi deskriptif idalam penelitiani ini iakan digunakan iuntuk mengetahuii distribusii frekuensi jawabani responden iatas ihasil pengumpulan ikuesioner yang idilakukan.

2. Analisis Regresi Linear Berganda

Analisis Regresi Linear Berganda digunakan untuk mengetahui pengaruh Motvasi, Komitmen
Organisasi, Pengawasan terhadap Kinerja Pegawai, Oleh karena itu digunakan teknik analisis Regresi linear berganda menggunakan software SPSS versi 19 dengan persamaan :

Keterangan :

$$
\mathbf{Y}=\alpha+\beta X 1+\beta X 2+\beta X 3+\text { ei }
$$

$\mathrm{Y}=$ Kinerja Karyawan

$\mathrm{X} 1=$ Motivasi

$\mathrm{X} 2=$ Komitmen Organisasi

$\mathrm{X} 3=$ Pengawasan

$\alpha=$ Konstanta

$\beta=$ Koefesien

ei $=$ Error Term

3. Uji Asumsi Klasik

Penggunaan analisis regresi sebagai model analisis harus memenuhi asumsi klasik. Asumsi klasik (asumsi dasar) dalam model regresi diperlukan untuk menghasilkan penaksir yang tidak bias, terpenuhinya asumsi dasar maka penaksiran koefisien yang diperoleh tidak bias, sebaliknya jika asumsi dasar yang tidak terpenuhi mengakibatkan penaksiran koefisiennya menjadi bias yang pada akhirnya dapat menimbulkan interpretasi dan kesimpulan yang salah.

\section{HASIL DAN PEMBAHASAN}

Hasil Analsis Regresi Linier Berganda

Pengujian hipotesis dengan menggunakan metode analisis regresi linear berganda, dan untuk mengetahui adanya pengaruh antara Motivasi (X1), Komitmen Organisasi (X2) dan Pengawasan (X3) terhadap Kinerja Pegawai (Y).

Tabel 2

Hasil Analisis Regresi Linear Berganda

\begin{tabular}{llccc}
\hline \multirow{2}{*}{ Model } & \multicolumn{2}{c}{$\begin{array}{c}\text { Unstandardized } \\
\text { Coefficients }\end{array}$} & $\begin{array}{c}\text { Standardized } \\
\text { Coefficients }\end{array}$ \\
\cline { 2 - 5 } & B & Std. Error & Beta \\
\hline 1 & 1.706 & 5.744 & \\
\cline { 2 - 5 } & (Constant) & .731 & .123 & .423 \\
\hline Motivasi & .490 & .195 & .213 \\
\hline Komitmen_organisasi & .922 & .166 & .454
\end{tabular}

Sumber : Data Lampiran yang di olah, 2020

Berdasarkan tabel diatas maka dapat diketahui model persamaan dari regresi linear berganda yang diperoleh adalah sebagai berikut :

$$
\begin{aligned}
& \mathrm{Y}=\alpha+\beta \mathrm{X} 1+\beta \mathrm{X} 2+\beta \mathrm{X} 3+\mathrm{ei} \\
& Y=1,706+0,731 \mathrm{X} 1+0,490 \mathrm{X} 2+0,922 \mathrm{X3}+\mathrm{ei} \\
& \begin{array}{lllll}
\mathrm{S} & = & \mathbf{0 , 4 2 3} & \mathbf{0 , 2 1 3} & \mathbf{0 , 4 5 4}
\end{array}
\end{aligned}
$$


Persamaan dari regresi tersebut dapat dijelaskan sebagai berikut :

1. Konstanta

Nilai konstanta sebesar 1,706 hal ini berarti bahwa jika variable Motivasi, Komitmen Organisasi, Pengawasan tetap atau tidak mengalami perubahan atau pengurangan, maka Kinerja Karyawan PT. Kalimantan Prima Persada (KPP) Banjarmasin sebesar 1,707 satuan.

2. Koefesien regresi variable Motivasi (X1)

Koefesien regresi variabel Motivasi memiliki arahan positif dalam pengaruhnya terhadap kinerja karyawan, ketika variabel Motivasi ditingkatkan 1 kali, maka kinerja karyawan pada Karyawan PT. Kalimantan Prima Persada (KPP) Banjarmasin akan meningkat sebesar 0,731 kali atau $73,1 \%$.

3. Koefesien regresi variabel Komitmen Organisasi (X2)

Koefesien regresi variabel Komitmen Organisasi memiliki arahan positif dalam pengaruhnya terhadap kinerja karyawan, ketika variabel Komitmen Organisasi ditingkatkan 1 kali, maka kinerja karyawan pada Karyawan PT. Kalimantan Prima Persada (KPP) Banjarmasin akan meningkat sebesar 0,490 kali atau $49 \%$.

4. Koefesien regresi variabel Pengawasan (X3)

Koefesien regresi variabel Pengawasan memiliki arahan positif dalam pengaruhnya terhadap kinerja karyawan, ketika variabel Pengawasan ditingkatkan 1 kali, maka Kinerja Karyawan pada Karyawan PT. Kalimantan Prima Persada (KPP) Banjarmasin akan meningkat sebesar 0,922 kali atau $92,2 \%$.

\section{Uji Hipotesis}

1. Uji F (simultan)

Uji F (simultan) diuji dengan menggunakan tabel Analysis of Varians (ANOVA) sebagai berikut:

Tabel 3

Analysis of Varians (ANOVA)

\begin{tabular}{llrrrrr}
\hline \multicolumn{7}{c}{ ANOVA $^{\mathbf{b}}$} \\
\hline \multirow{2}{*}{ Model } & $\begin{array}{c}\text { Sum of } \\
\text { Squares }\end{array}$ & \multicolumn{1}{c}{ df } & $\begin{array}{c}\text { Mean } \\
\text { Square }\end{array}$ & \multicolumn{1}{c}{ F } & Sig. \\
\hline \multirow{2}{*}{1} & Regression & 1546.895 & 3 & 515.632 & 55.015 & $.000^{\mathrm{a}}$ \\
\cline { 2 - 8 } & Residual & 618.591 & 66 & 9.373 & & \\
\cline { 2 - 7 } & Total & 2165.486 & 69 & & &
\end{tabular}

a. Predictors: (Constant), Pengawasan, Motivasi, Komitmen Organisasi

b. Dependent Variable: Kinerja Karyawan

Sumber: Data lampiran diolah, 2020

Berdasarkan Tabel 4.14 diatas, diketahui bahwa $F_{\text {hitung }}=55,015$ dibandingkan dengan $\mathrm{F}_{0,05 ; 70}$ $=2,74$ maka $F_{\text {hitung }}>F_{0,05 ; 70}$, dengan demikian maka Motivasi $\left(\mathrm{X}_{1}\right)$, Komitmen Organisasi $\left(\mathrm{X}_{2}\right)$ dan Pengawasan $\left(\mathrm{X}_{3}\right)$ secara simultan berpengaruh signifikan terhadap Kinerja Karyawan.

2. Uji t (Parsial)

Uji t atau uji parsial adalah uji yang digunakan untuk menguji hipotesis secara parsial, variabel independent terhadap variabel dependen dengan menggunakan tabel coefficients sebagai berikut:

Tabel 4

Hasil Uji t (Parsial)

\begin{tabular}{|c|c|c|c|c|c|c|}
\hline \multirow{2}{*}{\multicolumn{2}{|c|}{ Model }} & \multicolumn{2}{|c|}{$\begin{array}{c}\text { Unstandardized } \\
\text { Coefficients }\end{array}$} & \multirow{2}{*}{$\begin{array}{c}\text { Standardized } \\
\text { Coefficients } \\
\text { Beta }\end{array}$} & \multirow{2}{*}{$\mathrm{t}$} & \multirow{2}{*}{ Sig. } \\
\hline & & B & Std. Error & & & \\
\hline 1 & (Constant) & 1.706 & 5.744 & & .297 & .767 \\
\hline & Motivasi & .731 & .123 & .423 & 5.942 & .000 \\
\hline & $\begin{array}{l}\text { Komitmen } \\
\text { Organisasi }\end{array}$ & 490 & .195 & .213 & 2.508 & .015 \\
\hline & Pengawasan & .922 & .166 & .454 & 5.560 & .000 \\
\hline
\end{tabular}

Sumber : Data Lampiran yang di olah, 2020

Berdasarkan tabel 4.15 diatas menunjukkan hasil perhitungan $t$ hitung dari setiap variabel $\mathrm{X} 1, \mathrm{X} 2$ dan X3 dengan nilai $\mathrm{p}>0,05$, apakah berpengaruh secara signifikan terhadap perubahan nilai variabel dependen $\mathrm{Y}$ dengan cara membandingkan ttabel dengan $\mathrm{N}=$ jumlah sampel 70 beserta $\alpha=0,05$ di dapat tabel $=$ maka $t_{\alpha ; n}-1=t_{0,05 ; 70}$ sebesar 1,666, maka dihasilkan:

1. Variabel Motivasi $\left(\mathrm{X}_{1}\right)$

Uji t terhadap variabel Motivasi $\left(\mathrm{X}_{1}\right)$, didapatkan $t_{\text {hitung }}$ sebesar 5,942 dengan signifikansi t sebesar 0,000 , karena thitung sebesar 1,674 lebih besar dari $\mathrm{t}_{\text {tabel }}=1,666$ ( $\mathrm{t}_{\text {hitung }}>\mathrm{t}_{\text {table }}$ ), maka secara parsial $\mathrm{H}_{1}$ diterima dan $\mathrm{H}_{0}$ ditolak artinya Motivasi $\left(\mathrm{X}_{1}\right)$ secara parsial berpengaruh signifikan terhadap Kinerja Karyawan (Y) PT. Kalimantan Prima Persada (KPP).

2. Variabel Komitmen Organisasi $\left(\mathrm{X}_{2}\right)$

Uji t terhadap variabel Komitmen Organisasi $\left(\mathrm{X}_{2}\right)$, didapatkan thitung sebesar 2,508 dengan 
signifikansi t sebesar 0,015, karena thitung sebesar 0,061 lebih besar dari $t_{\text {tabel }}=1,666(\mathrm{t}$ hitung $<\mathrm{t}$ table), maka secara parsial $\mathrm{H}_{1}$ diterima dan $\mathrm{H}_{0}$ ditolak artinya Komitmen Organisasi $\left(\mathrm{X}_{2}\right)$ secara parsial berpengaruh signifikan terhadap Kinerja Karyawan (Y) PT. Kalimantan Prima Persada (KPP).

3. Variabel Pengawasan $\left(\mathrm{X}_{3}\right)$

Uji t terhadap variabel Variabel Pengawasan $\left(\mathrm{X}_{3}\right)$, didapatkan $t_{\text {hitung }}$ sebesar 5,560 dengan signifikansi t sebesar 0,000, karena thitung sebesar 5,560 lebih besar dari $\mathrm{t}_{\text {tabel }}=1,666\left(\mathrm{t}_{\text {hitung }}>\mathrm{t}_{\text {table }}\right.$ ), maka secara parsial $\mathrm{H}_{1}$ diterima dan $\mathrm{H}_{0}$ ditolak artinya Pengawasan $\left(\mathrm{X}_{3}\right)$ secara parsial berpengaruh signifikan terhadap Kinerja Karyawan (Y) PT. Kalimantan Prima Persada (KPP).

Pembahasan

1. Pengaruh Motivasi terhadap Kinerja Karyawan

Motivasi mempunyai pengaruh positif signifikan terhadap Kinerja Karyawan, artinya Faktor Intern dan Faktor Ekstern dapat membentuk Motivasi dengan baik dan dapat mempengaruhi Kinerja Karyawan PT. Kalimantan Prima Persada (KPP).

PT. Kalimantan Prima Persada (KPP) harus mengevaluasi kembali kebijakannya dalam hal Motivasi hal ini tentunya akan dapat mempengaruhi Kinerja Karyawan, untuk mendapatkan Motivasi yang dapat mempengaruhi Kinerja Karyawan dengan baik pada PT Kalimantan Prima Persada, maka harus mengevaluasi kebijakannya dalam beberapa hal sebagai berikut:

1) Harus ada peran supervise dalam suatu pekerjaan guna memberikan arahan dan bimbingan kerja.

2) Harus ada Jaminan karir untuk masa depan para karyawan

3) Kondisi lingkungan kerja seperti fasilitas, kebersihan, pencahayaan, ketenangan serta hubungan kerja antar sesama karyawan harus baik

4) Harus memiliki peraturan yang jelas dan fleksibel

5) Penghasilan utama tentunya dapat menghidupi diri beserta keluarga

Sehingga hal-hal tersebut diatas dapat mendorong kembali Variabel Motivasi melalui Indikator
Faktor Ekstern sehingga dapat mendorong kembali Kinerja Karyawan menjadi lebih Baik.

2. Pengaruh Komitmen Organisasi terhadap Kinerja Karyawan

Hasil penelitian ini menunjukkan bahwa Komitmen Organisasi tidak berpengaruh signifikan terhadap Kinerja Karyawan, artinya Affective Commitment, Continuance Commitment, Normative Commitment, belum dapat membentuk Komitmen Organisasi dengan baik dan tidak dapat mempengaruhi Kinerja Karyawan PT. Kalimantan Prima Persada (KPP).

Komitmen organisasi merupakan rasa kepercayaan akan nilai-nilai organisasi, serta kesetiaan terhadap organisasi untuk berkarya dan memilki keinginan yang kuat untuk bertahan di organisasi sehingga manfaat komitmen organisasi seperti menghindari biaya pergantian karyawan yang tinggi, mengurangi atau meringankan supervisi karyawan, meningkatkan efektifitas organisasi dapat dirasakan secara langsung oleh PT. Kalimantan Prima Persada (KPP), dengan adanya Komitmen Organisasi terhadap Karyawan PT. Kalimantan Prima Persada (KPP) maka akan mendorong kembali Kinerja Karyawan menjadi lebih baik lagi.

Komitmen organisasi sangat dibutuhkan oleh karyawan PT. Kalimantan Prima Persada (KPP), karena dengan adanya Affective Commitment, Continuance Commitment, Normative Commitment ini akan memberikan dorongan terhadap Komitmen Organisasi yang dapat mempengaruhi Kinerja Karyawan PT. Kalimantan Prima Persada (KPP) untuk lebih baik lagi.

PT. Kalimantan Prima Persada (KPP) harus mengevaluasi kembali kebijakannya dalam hal Komitmen Organisasi yang diberikan kepada karyawannya yang nantinya akan dapat mempengaruhi Kinerja Karyawan

3. Pengaruh Pengawasan terhadap Kinerja Karyawan

Pengawasan mempunyai pengaruh positif signifikan terhadap Kinerja Karyawan, artinya Kontrol Masukan, Kontrol Perilaku, Kontrol Pengeluaran dapat membentuk pengawasan dengan baik serta dapat mempengaruhi Kinerja Karyawan PT. Kalimantan Prima Persada (KPP).

Dengan adanya Pengawasan terhadap Kayawan PT. Kalimantan Prima Persada (KPP), maka kegiatan 
ini dilakukan dalam usaha menilai hasil pekerjaan serta mengadakan tindakan bila terjadi penyimpangan-penyimpangan agar tujuan dapat tercapai sesuai dengan rencana yang telah ditetapkan sangat penting.

Pengawasan berpengaruh secara signifikan terhadap Kinerja Karyawan hal ini akan terus diusahakan agar apa yang direncanakan menjadi kenyataan, keberhasilan suatu organisasi dalam emncapai tujuan yang telah ditetapkan tergantung kepada orang-orang yang berada dilingkungan tersebut, sehingga fungsi manajemen perusahaan akan berjalan secara efesien yaitu dengan adanya fungsi controlling. Hal ini juga sangat dibutuhkan oleh karyawan PT. Kalimantan Prima Persada (KPP), karena dengan adanya Pengawasan yang berada pada posisi akhir dari fungsi-fungsi manajemen lebih bermakna sebagai kunci kesuksessan seluruh dari pelaksanaan fungsi manajemen, seorang pimpinan harus melakukan pengawasan terhadap bawahan dalam melakukan pekerjaan guna mempertahankan dan meningkatkan kinerja karyawan.

PT. Kalimantan Prima Persada (KPP) harus mengevaluasi kembali kebijakannya dalam hal Pengawasan yang diberikan kepada karyawannya yang nantinya akan dapat mendorong kembali Kinerja Karyawan.

\section{KESIMPULAN DAN SARAN}

Kesimpulan

Motivasi, Komitmen Organisasi dan Pengawasan secara simultan berpengaruh signifikan dan dengan arah positif terhadap Kinerja Karyawan PT. Kalimantan Prima Persada (KPP). Hal ini memberikan makna jika Motivasi, Komitmen Organisasi dan Pengawasan secara simultan pada Karyawan PT. Kalimantan Prima Persada (KPP) semakin baik (positif), maka Kinerja Karyawan akan semakin meningkat. Sebaliknya, jika Motivasi, Komitmen Organisasi dan Pengawasan pada Karyawan PT. Kalimantan Prima Persada (KPP) secara simultan kurang baik (negatif), maka Kinerja Karyawan semakin menurun.

Pengawasan merupakan variabel yang berpengaruh dominan terhadap Kinerja Karyawan PT. Kalimantan Prima Persada (KPP), karena berdasarkan hasil uji Motivasi, Komitmen Organisasi dan Pengawasan terhadap kinerja karyawan PT. Kalimantan Prima Persada (KPP), diketahui variabel pengawasan mempunyai pengaruh yang paling dominan, dibandingkan variabel Motivasi dan Komitmen Organisasi.

Saran

Berdasarkan pembahasan dan kesimpulan yang telah dilakukan, dapat dikemukakan saran-saran sebagai berikut :

1. Saran pada Pimpinan PT. Kalimantan Prima Persada (KPP), perlu mendorong lagi motivasi dan komitmen organisasi yang dimiliki oleh karyawan agar Kinerja Karyawan dapat ditingkat lagi.

2. Saran pada karyawan, perlu memiliki motivasi yang tinggi dan berkomitmen penuh terhadap kemajuan PT. Kalimantan Prima Persada (KPP) karena akan berdampak kepada karyawan juga pada akhirnya bila perusahaan makin maju dan berkembang.

3. Saran pada peneliti selanjutnya, yang akan melakukan penelitian sejenis, diharapkan mengambil indikator-indikator lainnya. dan selanjutnya dalam tahapan pengumpulan data.

\section{REFERENSI}

[1] A.A Anwar Prabu Mangkunegara (2012). Manajemen Sumber Daya Manusia. Bandung: PT. Remaja Rosdakarya.

[2] A.A. Anwar Prabu Mangkunegara. 2011. Manajemen Sumber Daya Manusia Perusahaan. PT. Remaja Rosda Karya, Bandung

[3] Abrivianto, Okto P, dkk. 2014. Pengaruh Motivasi Kerja dan Komitmen Organisasional Terhadap Kinerja Karyawan HRD PT. Arthawena Sakti Gemilang Malang. Jurnal Administrasi Bisnis. Vol. 7. No. 2 Januari 2014.

[4] Bernardin, John H., dan Russel, Joyce E. A., Human Resources Managment: An Experiental Approach (Jakarta: Gramedia Pustaka, 1993).

[5] Darmawan. 2013. Metode Penelitian Kuantitatif. Bandung: Remaja Rosdakarya.

[6] Edy Sutrisno, 2013. Manajemen Sumber Daya Manusia. Cetak Ke Enam. Pranada Media Group, Jakarta.

[7] Fahmi, Irham. (2010). Manajemen Kinerja Teori dan Aplikasi. Geger Kalong Hilir., Bandung: Alfabeta

[8] Hasibuan, Malayu S.P. 2010. Manajemen Sumber Daya Manusia. Jakarta: PT Bumi Aksara. 
[9] Mar'at. (2000). Sikap Manusia: Perubahan serta Pengukurannya. Bandung : Ghalia Indonesia.

[10] Moorhead dan Griffin. 2013. Perilaku Organisasi. Jakarta: Salemba Empat.

[11] Purnama Womarianing Nurul. 2016. Pengaruh Motivasi Kerja terhadap Komitmen Organisasional dan Kinerja Karayawan (Studi pada Karyawan Bank BRI Cabang Kawi Malang. Jurnal Adminitrasi Bisnis. Volume. 40 No. 2

[12] Ranupandojo dan Husnan, 2002, "Organisasi dan Motivasi: Pasar Peningkatan Produktivitas", Bumi Angkasa, Jakarta.

[13] Robbins SP, dan Judge. 2007. Perilaku Organisasi, Jakarta : Salemba Empat
[14] Robbins, P. Stephen dan Timothy A. Judge. 2011. Perilaku Organisasi. Salemba Empat. Jakarta

[15] Simamora, Henry. (2007). Manajemen Pemasaran Internasional. Jilid II Edisi 2. Jakarta: PT Rineka Cipta.

[16] Veithzal Rivai. (2011). Manajemen Sumber Daya Manusia Untuk Perusahaan Dari Teori Ke Praktek. PT. Raja Grafindo Persada, Jakarta. 